\title{
KRAJOBRAZ W TURYSTYCE KULTUROWEJ - PRZYKŁAD OSADNICTWA OLĘDERSKIEGO W WIELKOPOLSCE
}

\section{Krajobraz kulturowy}

Wyznaczając obszary atrakcyjne dla turystyki, zwraca się uwagę na wyjątkowość krajobrazu, jego urozmaicenie - bogactwo skarbów natury, a więc elementów naturalnych, ale również kulturowych. Regiony nadmorskie, dzikie plaże, pojezierza z dziesiątkami urokliwych jezior, góry ze schroniskami i szlakami wspinaczek są same w sobie atrakcyjnymi przestrzeniami dla szeroko pojmowanej turystyki. Drugie kryterium, które stosuje się przy rozpatrywaniu krajobrazu, to elementy kultury, które kształtuje człowiek i jego działanie. Inność, egzotyka, wielobarwność kulturowa, swoisty folklor, regionalizm, zabytki - to pojęcia, których odkrywanie stanowi niezwykły walor na wielu turystycznych szlakach. Gdy obie cechy zarówno przyrodnicze, jak i kulturowe spotkają się na jednym obszarze (czyli w krajobrazie), to tworzy się specyficzna całość. O turystyce kulturowej zwykle mówi się wtedy, kiedy podstawowym impulsem jest chęć zwiedzenia obiektów stworzonych i ukształtowanych przez człowieka jako nosiciela kultury. Do nich należą: miejsca historyczne, archeologiczne i etnograficzne, pałace, zamki, muzea, galerie, parki, ogrody, zespoły urbanistyczne, obiekty sakralne, trasy turystyczne związane z określoną tematyka, obiekty techniczne, a także wydarzenia kulturalne i festiwale (Gaworecki, 2010).

Jednak istnieje także inny rodzaj aktywności turystycznej, często traktowany jako niszowy - wykorzystujący przestrzenie, które wydawałyby się zupełnie pozbawione szczególnych atrakcji. Przez lata zapomniane i degradowane z lokalnym przeświadczeniem o braku cech wyróżniających, leżące daleko od głównych szlaków. Tereny takie istnieją i od jakiegoś 
czasu obserwuje się wzrost zainteresowania nimi. Lokalni badacze - pasjonaci i organizacje turystyczne - a czasem przypadkowe zdarzenia ukazują takie tereny z zupełnie innego punktu widzenia, odkrywając to, co ukryte, tajemnicze, zapomniane. Wejście turysty w taką przestrzeń wiąże się z umiejętnością odczytywania często mocno zatartych już śladów. Dla turystyki kulturowej jest to dodatkowy bodziec, aktywizujący sferę doznań. Podróże takie bardzo często zamieniają się w pełną przygód wyprawę w nieznany świat, który wymaga odpowiedniego przygotowania oraz wytrawnego przewodnika wywodzącego się często z lokalnych animatorów krajoznawstwa. Ten rodzaj aktywności turystycznej z punktu widzenia historyczno-kulturowego jest dziedziną obejmującą całokształt działalności poznawczej oraz utrwalającej wyniki zainteresowań (własne poszukiwania i analiza publikacji, map, tworzenie dokumentacji - zdjęć, filmów, nagrań itp.). Obejmuje również stosowanie wypracowanych metod i techniki działalności krajoznawczej. Ten rodzaj turystyki, dalekiej od utartych szlaków i opisów w przewodnikach, uruchamia indywidualną aktywność i pełni rolę wychowawczą oraz funkcję społecznej edukacji międzykulturowej, dającej orientację i wiedzę o otaczającej rzeczywistości przyrodniczej, społecznej i kulturowej oraz umiejętności i nawyki właściwych zachowań turystycznych. Jest środkiem służącym do podnoszenia poziomu kultury i rozwoju osobowości (Gaworecki, 2010). Taki rodzaj aktywności daje także umiejętność „,czytania krajobrazu”, czyli odkrywania znaków często bardzo widocznych i bliskich, a jednak wymagających wiedzy i ciągłego doświadczania i interpretowania.

Krajobraz kulturowy to wszystko to, co człowiek zdołał przez wiele stuleci wytworzyć i pozostawić po sobie. Bardzo specyficzna forma ludzkiej ingerencji - wielowiekowej pracy - widoczna jest na wsi. Jest wypadkową tego, co naturalne oraz tego co kulturowe. Kultura to forma adaptacji człowieka do zastanych form środowiskowych, która w zależności od warunków geograficznych oraz działalności człowieka przybiera różne formy. Mogą to być procesy związane z przekształcaniem środowiska naturalnego, ale także zmiany zachodzące w świadomości samych mieszkańców, którzy czują się związani ze swoim miejscem zamieszkania. (Frydryczak, Angutek, 2014). W takim ujęciu krajobraz kulturowy jest pojęciem obejmującym wiele zjawisk widocznych i rozpoznawalnych w pejzażu, np.: układów pól, łąk, dróg, kanałów, usypanych grobli, zasadzonych drzew i lasów celowo utworzonych przez człowieka, a także kształtów wsi od owalnicy, rzędówki i ulicówki po rozproszone osady samotnicze. W skład krajobrazu przekształconego przez człowieka wchodzą także typy gospodarstw, architektura gospodarcza 
i mieszkalna, kościoły wiejskie, zabudowania użyteczności publicznej, a także tak zwana mała architektura, np. krzyże i kapliczki przydrożne oraz cmentarze. Do istotnych części wiejskiego krajobrazu kulturowego zalicza się także elementy związane $\mathrm{z}$ niematerialnym dziedzictwem człowieka i jego aktywnością. Ich poznanie wymaga trudu zagłębienia się w różnorakich nurtach kultury typu ludowego. Specyficzny rodzaj spuścizny odziedziczonej po przodkach stanowi inspiracje dla kolejnych pokoleń artystów, twórców, naukowców (Lowenthal, 2014). Tradycje polskiej wsi zbudowane są z dorobku wielu pokoleń, przedstawicieli różnych grup regionalnych i etnicznych. Ta różnorodność jest efektem funkcjonowania w niejednorodnych warunkach geograficznych oraz swoistych „negocjacji z naturą". Tak powstaje zróżnicowanie kulturowe, widoczne w gwarach i dialektach, tradycyjnym pożywieniu, sposobach obchodzenia świąt, budownictwie oraz zdobieniu stroju odświętnego. Wszystkie elementy widoczne gołym okiem, jak i te ukryte wewnątrz tzw. ludowej wizji świata lokalnej społeczności, razem z bogactwem inności, przyzwyczajeń, zwyczajów, obrzędów, zachowań, wiedzy, a także kultywowanych wartości, wchodzą w swoisty kanon krajobrazu kulturowego danego regionu. Należy podkreślić, iż szczególną wartość poznawczą w czytaniu wyznaczników krajobrazu kulturowego mają terytoria pogranicza różnych kultur. To miejsca mieszania wzorców kulturowych, dyfuzji i wymiany oraz styku i wyraźnych granic kulturowych. To także przestrzenie naznaczone kontrastami, konfliktami i nieporozumieniami, jak również ogromem poszukiwania pomostów, rozbrajania stereotypów i chęci testowania swojej tolerancji.

\section{Osadnictwo na prawie olęderskim w Polsce}

Ślady dawnego osadnictwa holenderskiego można odnaleźć na wielu obszarach w Polsce, np. na Żuławach, Powiślu, rozlewiskach Bugu oraz kilku mikroregionów Wielkopolski. Proces ten przyjął nazwę osadnictwa na prawie olęderskim i w latach 1547-1864 stanowił znaczący model sprowadzania na tereny Rzeczypospolitej osadników. Przez pierwsze stulecie głównie z udziałem osadników z Niderlandów oraz ich potomków, a w kolejnych wiekach na prawie olęderskim osadzano Niemców, Czechów oraz Polaków, zachowując przy tym ogólną dla nich nazwę: Olędrzy (Chodyła, 2007). W rozważaniach dotyczących krajobrazu kulturowego ukształtowanego w wyniku tych ruchów osadniczych "olęderskość" jest rodzajem zagadki, tajemnicy, która wzbudza ciekawość szczególnie, 
gdy mija się miejscowości o charakterystycznych nazwach, np. Polskie Olędry (fot. 1), Olędry Wielkie, Olędry Henrykowskie, Wrączynkowskie Holendry, Holędry Różańskie itp. W dwutomowym spisie miejscowości jest takich nazw kilkadziesiąt (Spis miejscowości w Polsce, 2000).

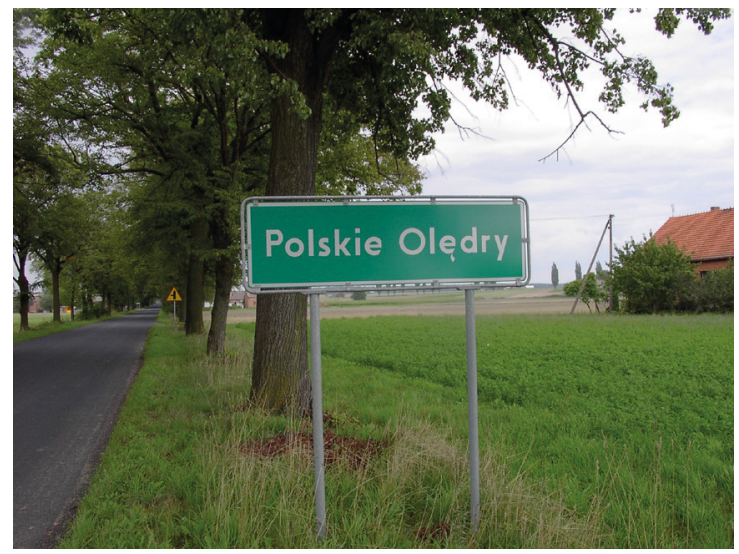

Fotografia 1. Polskie Olędry k. Koźmina Źródło: W. Przewoźny (2006)

Trudne uwarunkowania społeczne, gospodarcze, polityczne, czasem prześladowania religijne zmuszały ludzi do opuszczania swojego miejsca i poszukiwania krainy bezpiecznej, tolerancyjnej dla odmienności i oferującej nadzieję na lepsze życie. Taka właśnie sytuacja w Niderlandach w połowie XVI w., a później również w innych krajach zachodniej Europy, wypchnęła na rodzaj tułaczki tysiące mocno zmotywowanych migrantów - w większości bezrolnych chłopów, doświadczonych meliorantów zatrudnianych niegdyś przy budowie polderów, ludzi zagrożonych represjami w toku szaleństwa wojen religijnych doby reformacji (Przewoźny, 2007). Takich ludzi zapraszano do Rzeczypospolitej w czasie złotego wieku dynastii Jagiellonów. Bogate, dobrze zarządzane państwo potrzebowało ludzi - specjalistów w zagospodarowywaniu trudnych terenów zalewowych Żuław regulujących ujście Wisły oraz innych obszarów, których nikt dotychczas nie był w stanie okiełznać. To oni otrzymali specjalne prawo lokacyjne nazwane Holenderskim, a polscy królowie gwarantowali im przywileje, które pomagały zakładać wioski i zapewniały wolność osobista, religijną i gospodarczą. Olędrami nazywano w pierwszej kolejności przybyszów z Niderlandów, Flandrii, Fryzji (od nich przyjęła się nazwa Holendrzy w spolszczonej wersji-Olędrzy), ale także późniejszych osadników z Prus, Saksonii, Frankonii i Palatynatu, Szwabii, Wirtembergii 
oraz Śląska, Moraw i Czech. Inny język, religia (osadnicy byli najczęściej menonitami, kalwinami, luteranami, ewangelikami), lecz przede wszystkim inna kultura, sposób życia, wiedza, światopogląd i system wartości powodowały także naturalny dystans i tendencję do dość stereotypowego widzenia tych obcych, kojarząc wszystkich z Niemcami. Ciągła zmienność w traktowaniu Olędrów - jako pracowitych i spokojnych sąsiadów, a innym razem jako obcych - widoczna jest $\mathrm{w}$ dalszym ciągu, mimo że ta fascynująca olęderska opowieść należy już do historii (Przewoźny, 2007). "Olędry" - miejsca oraz „Olędrzy" - ludzie są wspólnym określeniem na wielokulturowe i wieloetniczne zjawisko dotyczące także polskich chłopów, korzystających z dobrodziejstw olęderskiego prawa osadniczego, dającego wolność i poczucie gospodarowania „na swoim”. Jest to więc nazwa uniwersalna - określająca grupy chłopskich osadników, a także system prawny, czasem także wykonywany zawód. Historia trwającego ponad 400 lat zjawiska migracji ludności wiejskiej z wielu zakątków Europy i ich chęci znalezienia swojego miejsca do życia na terenach Żuław Wiślanych, Żuław Elbląskich i Malborskich, Pomorza, Kujaw, Wielkopolski, Mazowsza, Małopolski i Śląska jest dziś niezwykle trudna do odtworzenia.

Fale osadnicze w konkretnych okresach miały różne przyczyny i przebiegały inaczej w poszczególnych częściach kraju. Różna była narodowość i religia osadników oraz ich decyzje i warunki dotyczące typu tworzonych wiosek czy osad jako wysp kulturowych odizolowanych od bezpośrednich sąsiadów bądź przeciwnie - asymilowanych z wyraźną chęcią wtopienia się w lokalny krajobraz społeczny i kulturowy. Wreszcie zmienne były losy terytoriów, które zasiedlili. Po czasach względnego spokoju i tolerancji następowały okresy wojen, konfliktów, zniszczeń, podziałów, wyrastających granic i przynależności do różnych państwowości począwszy od okresu rozbiorów po 1945 r. Dawne prawa i przywileje, dane Olędrom przez polskich królów i szlachtę, w nowych okolicznościach przestawały być respektowane, a kolejne normy prawne nie były już tak tolerancyjne i atrakcyjne. Zmuszało to osadników do dalszych migracji lub całkowitego podporządkowania się. Olędrzy stali się również obiektem zewnętrznej indoktrynacji, narzucano im światopogląd zależnie od rosnących nacjonalizmów i fali ksenofobii. Nasilało się to szczególnie $\mathrm{w} X X \mathrm{w}$. - stuleciu wojen, chaosu, niewyobrażalnych eksterminacji całych narodów, wysiedleń, bezpowrotnie zerwanych delikatnych powiązań społecznych kształtowanych od wielu wieków (Przewoźny, 2007).

Historia Olędrów jest więc pełna zawirowań, nakładających się na siebie zjawisk, wypełniają ją także dramatyczne wydarzenia, które odbiły 
swoje piętno w ludzkich życiorysach. Wspólna dla wszystkich Olędrów była silna motywacja znalezienia swojego miejsca do życia, nawet $w$ tak wydawałoby się niesprzyjających temu warunkach naturalnych. Potwierdzeniu słuszności swoich niełatwych decyzji mogli poświęcić całą swoją wiedzę, kreatywność i ogrom pracy wielu pokoleń oraz ponosić, z większą lub mniejszą pokora, konsekwencje życia w oderwaniu od dawnych ojczyzn. Olęderską historię można dziś opowiedzieć, ukazując dość zatarte przez czas ślady, które po niej zostały. Najtrwalszym elementem okazał się krajobraz, który Olędrzy potrafili wymodelować w taki sposób, iż nawet po tylu latach, choć mocno zdewastowany, jest nadal czytelnym symbolem ich pracowitości. Krajobrazy nadrzecznych pól, łąk poprzecinanych kanałami, groblami, wyjątkowej urody podcieniowe chaty na Żuławach i wzdłuż Dolnej Wisły, charakterystyczne dla Olędrów układy wsi i zabudowa gospodarstw, rozłożyste wierzby, tak bardzo kojarzące się z typowym polskim krajobrazem, ale także pasy topoli sadzonych na miedzach oraz wzdłuż kanałów i usypanych wałów przeciwpowodziowych, ulokowane często na sztucznie usypanych terpach gospodarstwa, są niezatartym przez lata śladem ogromu pracy i determinacji $\mathrm{w}$ adaptowaniu niezwykle kapryśnego, często niebezpiecznego terenu należącego wcześniej jedynie do wodnego żywiołu (Klassen, 2002). Wszystko to można jeszcze zobaczyć w wielu regionach Polski. Niezwykłym przykładem dawnego olęderskiego budownictwa jest gospodarstwo w Chrystkowie (Christfelde) w okolicach Bydgoszczy. Całe domostwo wraz z częścią inwentarską kryte jest wspólnym dachem, a wejście do części mieszkalnej znajduje się w charakterystycznej wystawce z podcieniem (fot. 2).

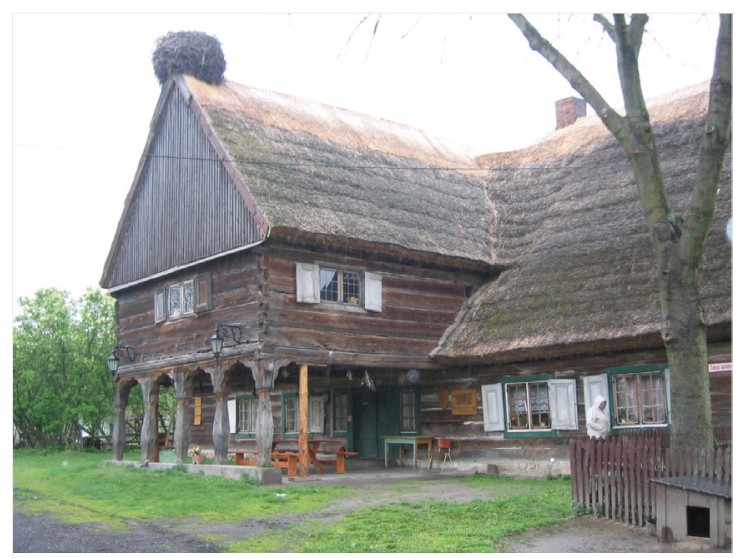

Fotografia 2. Chrystkowo - dom podcieniowy Źródło: W. Przewoźny (2006) 
Osadnictwo to zwykle kojarzy się z mennonitami - Holendrami na Żuławach Wiślanych, Elbląskich i Malborskich. Nic więc dziwnego, że właśnie tam występują szlaki turystyczne z adnotacją "Szlak Olędrów” lub „menonitów". Cieszą się one dużym powodzeniem, a z odkrywania zagadkowej historii pracowitych gości z Niderlandów zrobiono atrakcję turystyczną. Na tym terenie od wielu lat działają różne organizacje dbające o podtrzymanie wiedzy, m.in.: Stowarzyszenie Miłośników Nowego Dworu Gdańskiego - Klub Nowodworski, Żuławski Park Historyczny, Lokalna Organizacja Turystyczna. Organizacje te chronią także zapomniane do niedawna cmentarze, jak ukazany na fotografii $3 \mathrm{cmentarz}$ w Stogach Malborskich. Tuż obok cmentarza podziwiać można przykład okazałego olęderskiego gospodarstwa, nazywanego langhoff, także łączącego część mieszkalną z gospodarczą pod wspólnym dachem (fot. 4).

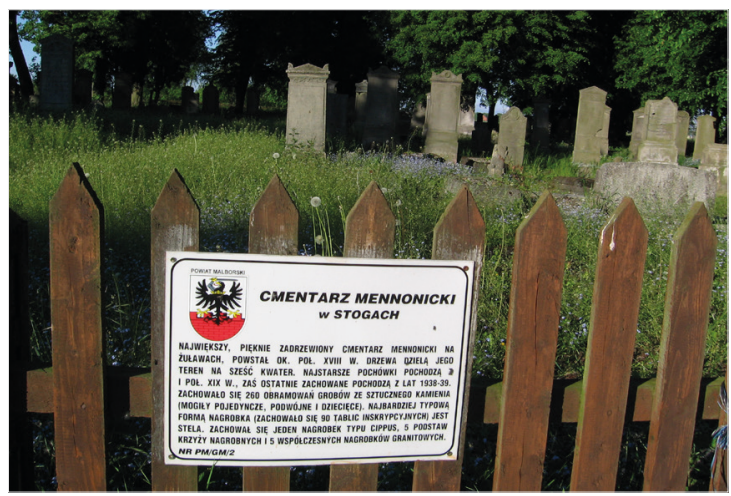

Fotografia 3. Cmentarz mennonitów w Stogach Malborskich Źródło: W. Przewoźny (2010)

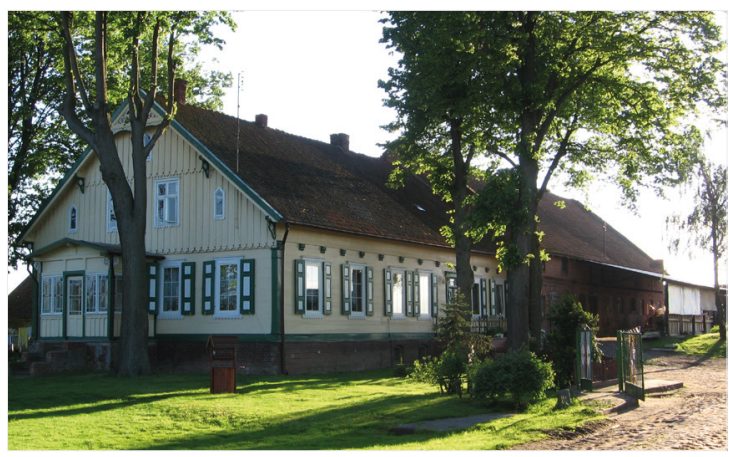

Fotografia 4. Dom typu langhoff w Stogach Malborskich Źródło: W. Przewoźny (2010) 


\section{Olędrzy w Wielkopolsce}

Wielkopolska od wieków była krainą otwartą dla przybyszów z różnych stron Europy, a jeżeli nie mieli złych zamiarów, ta ziemia okazywała się dla nich gościnna - dająca szansę na realizację życiowych zamierzeń. Dziś widoczne są jedynie ślady ich pobytu - pozostały osady i wioski, czasem stare gospodarstwa w środku puszczańskich samotni, specyficznie ukształtowane pola i łąki, kanały i groble, zdziczałe sady, cmentarze, których do niedawna nikt nie odwiedzał. Bardzo często brak jest świadomości, że najszerszym terytorium przeobrażonym przez Olędrów jest Wielkopolska (Burszta, 2014). Sukces z Żuław promieniował na dalsze tereny dóbr królewskich, szlacheckich i kościelnych wzdłuż biegu Wisły na południe, by już w 1597 r. dotrzeć do Wielkopolski Północnej (lokacja Ujskich Holendrów - dzisiejsze Ługi Ujskie k. Piły). Charakterystyczny krajobraz ukształtowany przez dawnych osadników można dziś zobaczyć wzdłuż północnych rozlewisk Noteci co ilustruje fotografia 5.

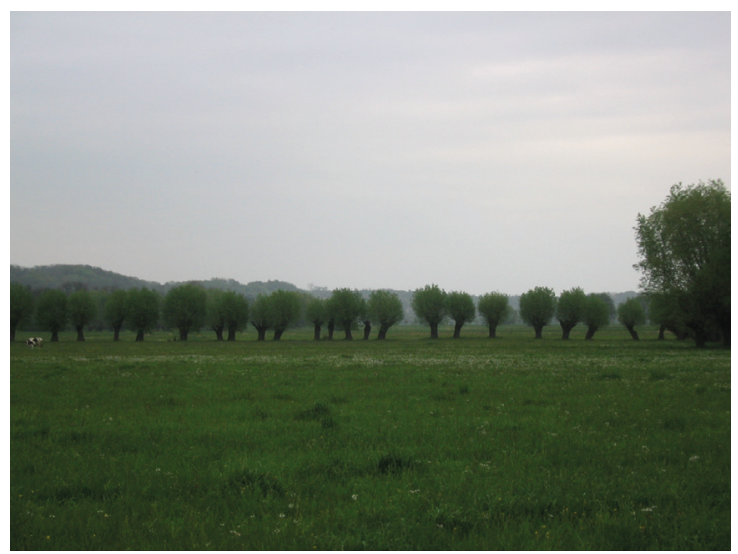

Fotografia 5. Krajobraz olęderski okolic Ług Ujskich w Wielkopolsce

Źródło: W. Przewoźny (2016)

W początkach XVII w. linia Noteci wyznaczała kierunek migracji potomków holenderskich osadników z przeludnionych już Żuław oraz nowych migrantów z innych terytoriów Europy zachodniej. Zakładano osady na wzgórzach doliny Noteci (Herburtowo, Folsztyn, Nowe Dwory, Marianowo i inne) (Przewoźny, Przewoźny, 2009). Wioski te stanowić mogą atrakcję turystyczna, i już są coraz częściej odwiedzane, z uwagi na malownicze położenie z charakterystycznym pasowym układem łąk i pól 
ułożonych prostopadle do Noteci, przy której są wyznaczone przystanie dla grup turystyki kajakowej. W miejscowościach tych pozostało również dużo śladów po Olędrach w postaci autentycznych domów modlitw, tzw. zborów mennonitów, oraz urokliwych aczkolwiek zaniedbanych cmentarzy. Na fotografii 6 ukazany jest jeden z najcenniejszych mennonickich zabytków w Wielkopolsce - dawny zbór w Nowych Dworach nad Notecia, kryjący w części za ołtarzem dwie szybki z 1615 r. z nazwiskami pierwszych sołtysów wsi.

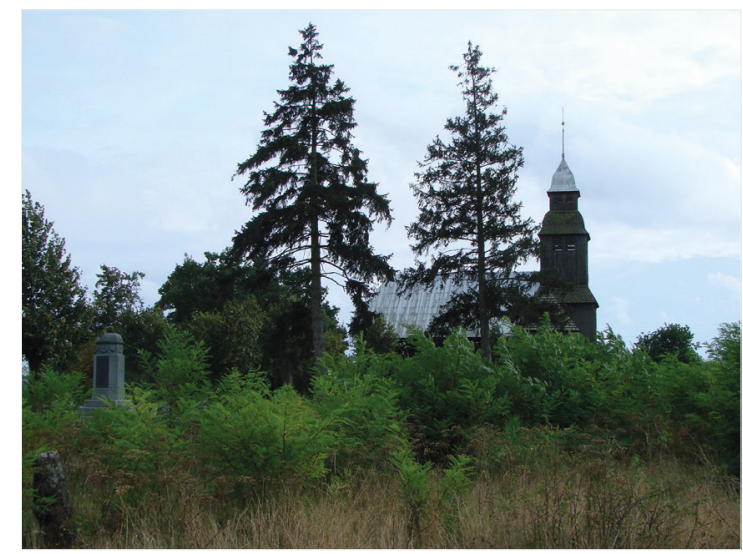

Fotografia 6. Dawny zbór mennonicki w miejscowości Nowe Dwory Źródło: W. Przewoźny (2016)

W Wielkopolsce powstawały zwarte regiony osadnictwa olęderskiego w Puszczy Noteckiej, ziemi nowotomyskiej, okolicach Nekli, Pyzdr, Konina, Gniezna - rozlewisk Noteci, Warty, Prosny. Założono tu ponad 900 osad i wiosek olęderskich (Chodyła, 2007).

\section{Puszcza Pyzdrska}

W odkryciu zupełnie nowych walorów turystycznych w wielkopolskich przestrzeniach osadnictwa olęderskiego szczególną rolę odgrywają wioski okolic Nekli oraz samotne osady Puszczy Pyzdrskiej. Puszcza ta to obszar o doskonale zachowanym dziedzictwie olęderskim, wyróżniający się dużą ilością starych zagród, często budowanych z darniowej rudy żelaza lub drewna. Wioski położone na terenie kilku gmin: Blizanów, Chocz, Gizałki, Grodziec, Pyzdry, Rychwał, Rzgów, Stawiszyn 
i Zagórów, stanowią rozległą sieć samotnych, lesistych i odizolowanych miejsc. W lasach tego obszaru przez stulecia wykształcił się specyficzny krajobraz kulturowy, będący wynikiem przekształceń dokonywanych przez osadników olęderskich, którzy na te tereny zaczęli przybywać od XVIII w. (Chodyła, 2015). Przez lata ludność pochodzenia głównie niemieckiego i polskiego współistniała obok siebie i dopiero wydarzenia, które nastąpiły po II wojnie światowej, doprowadziły do kolejnych istotnych przemian. Mieszkających na tych terenach Olędrów częściowo wysiedlono, a na ich miejsce zaczęli przybywać osadnicy $\mathrm{z}$ różnych stron Polski oraz ludność $\mathrm{z}$ ościennych regionów. $Z$ czasem ta mieszanka ludnościowa zaczęła się identyfikować z tym terenem. Nowi mieszkańcy Puszczy Pyzdrskiej zamieszkali w dawnych domach olęderskich i przyzwyczaili się do warunków, w jakich im przyszło żyć. Wyjątkowa dla tego terenu jest także obecność kilku rodzin - potomków dawnych Olędrów, których w wyniku zakrętów historii nie deportowano po wojnie. Mają oni ewangelickie parafie w Zagórowie i Nowej Kazimierce. Po latach zapomnienia i wykluczenia zaczynają opowiadać o swoich historiach. Na omawianym terenie działają organizacje, które z tych opowieści i odrębności kulturowej tworzą zrekonstruowany obraz wypełniony lokalnymi atrakcjami. Szczególnie warto zobaczyć wyniki działań Stowarzyszenia Kulturalnego „Echo Pyzdr" oraz Lokalnej Organizacji Turystycznej. Dzięki ich pracy turyści mają wyjątkową możliwość skorzystania z olęderskiego szlaku turystycznego, wypełnionego różnymi atrakcjami, jak np. możliwość zobaczenia starych domów „z żelaza” czy urokliwie położonych wiosek o wyjątko-

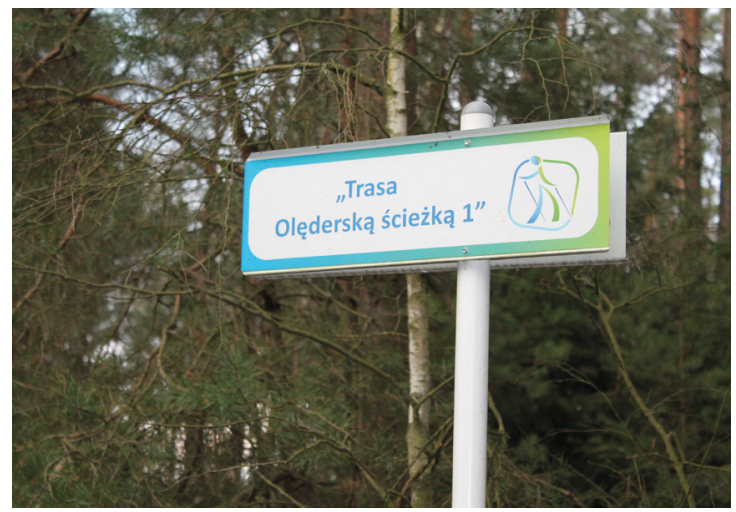

Fotografia 7. Szlak turystyczny w okolicach Nowolipska (Puszcza Pyzdrska) Źródło: W. Przewoźny (2010) 
wych walorach etnograficznego dziedzictwa, które in situ mogłyby z powodzeniem być zamienione $w$ żyjące skanseny. Niezwykle interesujący jest materiał, a więc ruda darniowa, z której zostało wykonane wiele budynków gospodarczych i mieszkalnych. Budownictwo z rudy spotyka się wprawdzie w innych regionach kraju, ale nigdzie nie występuje w takiej ilości i nie zachowało się tak wiele obiektów z niej wykonanych. Na fotografii 7 ukazano charakterystyczne oznakowanie jednej z wielu ścieżek szlaku prowadzącego przez tereny Puszczy Pyzdrskiej.

Obszar Puszczy Pyzdrskiej z piaszczystymi drogami jest terenem trudnym, ale tym bardziej atrakcyjnym dla turystów o określonych, wysokich wymaganiach. W czasach osadnictwa olęderskiego $w$ wielkich przestrzeniach lasu wycięto obszerne poręby, na których znajdują się do dzisiaj pola, łąki i samotne gospodarstwa. Przykładem takich wiosek mogą być malownicze Piskory, jak również wieś Nowolipsk. W tej ostatniej zachowały się gospodarstwa zbudowane $\mathrm{z}$ rudy żelaza w początku XIX w. $\mathrm{Na}$ fotografii 8 jedna $\mathrm{z}$ wielu starych chat - obecnie odrestaurowana i zamieniona $\mathrm{w}$ letniskowy dom rodzinny.

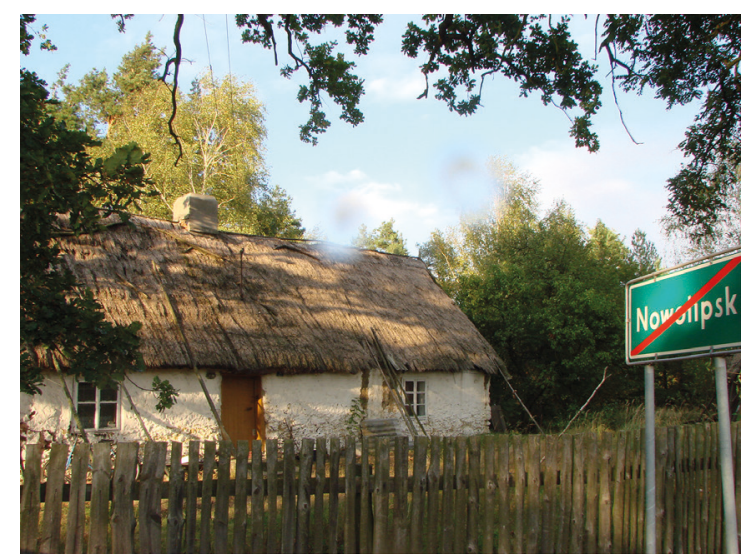

Fotografia 8. Nowolipsk - dom olęderski z darniowej rudy żelaza Źródło: W. Przewoźny (2010)

Wspomniane wsie otoczone są lasami, a pola uprawne przenikają się z fragmentami puszczy, zalesieniami śródpolnymi i drogami obrośniętymi drzewami. Całość, jako unikatowy układ krajobrazowy, wyróżnia się wyjątkowym urokiem, można powiedzieć, że w tych okolicach czas się zatrzymał. Zachowały się tam domy i budynki gospodarcze w stanie, w jakim je zbudowano, a często są to obiekty pochodzące z końca XVIII w. 
Tereny te nie są specjalnie przygotowane i otwarte na szerszy ruch turystyczny, lecz nie oznacza to, że wprawny poszukiwacz inności nie znajdzie na nich bogactwa różnorodności. Rozległe i urozmaicone obszary lasów Puszczy Pyzdrskiej z samotnymi miejscowościami, do których bardzo często trudno dojechać, obszary urokliwych rozlewisk Warty, Prosny i olęderska historia prawie 50 miejscowości może tworzyć wyjątkowy potencjał dla turystyki. Wszelkie trudy podróżowania po terenach Puszczy wynagradza krajobraz, także z wyjątkowymi zabytkami Pyzdr, Lądu, Ciążenia. Od kilku lat przez północną część regionu Pyzdr z biegiem Warty przebiega szlak żeglugowy „Wielka Pętla Wielkopolski” (Słowiński, 2006). Niedawno otwarta marina w Lądzie, tuż obok pocysterskiego zespołu klasztornego, stanowi także miejsce nie tylko wypoczynku dla wodniaków, ale jest także punktem wyjazdów do pobliskich miejscowości oraz niezwykłych terenów Nadwarciańskiego Parku Krajobrazowego.

\section{Nekielskie Olędry}

Zaledwie $30 \mathrm{~km}$ od granic Puszczy Pyzdrskiej położonych jest 10 olęderskich wiosek w okolicach Nekli. Tu także zachwyca krajobraz - na tyle, że mieszkańcy pobliskiej Wrześni, Gniezna i Poznania bardzo chętnie sytuują $w$ tej okolicy letnie domy i rekreacyjne działki, często nie zdając sobie sprawy z historii tych miejsc. Pokazany na fotografii 9 krajobraz Nekielskich Olędrów (obecnie Nekielka), staje się codziennym widokiem dla wielu nowych mieszkańców tych okolic.

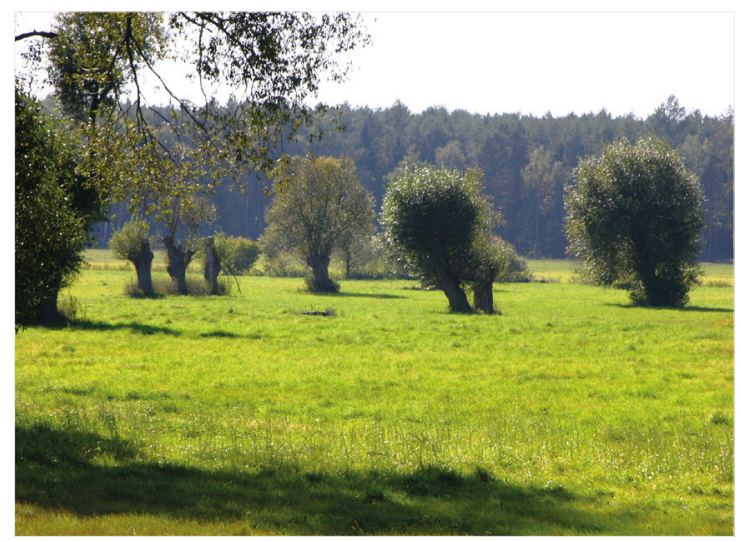

Fotografia 9. Nekielka - krajobraz Źródło: W. Przewoźny (2015) 
W okolicach Nekli, na sprawdzonych wcześniej w wielu regionach kraju wzorach prawnych, osadzono Olędrów w połowie XVIII w. (Chodyła, 2005, 2015). Rozległe i niezagospodarowane dotąd lesiste i podmokłe tereny stały się na kilka pokoleń ziemią oddaną w użytkowanie niemieckiej ludności luterańskiej, także tu nazywanej Olędrami. Jako pierwsze założono w 1749 r. Nekielskie Olędry (dzisiejsza Nekielka) oraz Brzezie (dzisiejsze Brzeźno), a w następnych latach: 1751 r. Góreckie Olędry - dzisiaj w granicach Nekli, Gierłatowo w 1775 r. (Gierłatowo Olędry, Chłapowskie Olędry), w 1756-1776 r. Barczyzna (Barskie Olędry i Mystkowskie Olędry), w 1759-1761 r. Zasutowo (Zasułtowo Olędry, Laski Olędry), w 1772 r. Siedleczek (Siedleckie Olędry). Dawne wsie olęderskie znajdują się dziś w granicach siedmiu miejscowości: Brzeźno i Siedleczek w gminie Kostrzyn w powiecie poznańskim; Barczyzna, Gierłatowo, Nekla, Nekielka, Zasutowo w gminie Nekla w powiecie wrzesińskim (Chodyła, 2015). Dzięki zagospodarowaniu lesistych i bardzo bagnistych terenów powstał charakterystyczny olęderski krajobraz. Wsie na karczunkach leśnych oraz powstałe na bagnach mają zabudowę rozproszoną. Każdy osadnik otrzymywał działkę najczęściej w kształcie prostokąta. Najpierw na środku działki lub na wzniesieniu powstawał plac pod budowę chaty, a dopiero później karczowano las i przygotowywano pola uprawne. Główna droga biegła nieregularnie przez całą wieś, łącząc ze sobą drogi dojazdowe do poszczególnych gospodarstw. Taki układ komunikacyjny zachował się do dzisiaj w Nekielce i Barczyźnie, gdzie stosunkowo łatwo pomylić drogi. Osady na tym terenie zakładali poszczególni właściciele ziemscy, należący do znanych rodów wielkopolskich, m.in.: Wilkońscy, Turno, Lipscy, Krzyccy, Zakrzewscy. Dla nich zaproszenie kierowane do osadników i nadawanie im praw z licznymi przywilejami gwarantowało zagospodarowanie trudnych nieużytków, a w efekcie wzrost dochodów. Natomiast dla Olędrów korzystne - znacznie lepsze niż obowiązujące w okolicach - warunki prawno-gospodarcze, wraz z zapewnioną tolerancją religijną i wolnością gospodarowania, stwarzały perspektywy znalezienia bezpiecznego i szczęśliwego gniazda rodzinnego. Odniesienie sukcesu zależało od nich samych - od ich pracowitości, wytrwałości, uporu i wiary we własne przeznaczenie. Los okazał się dla osadników pełen zaskakujących zmian i dramatycznych wydarzeń, często zmuszani byli do dalszej wędrówki, szczególnie od początku XIX w., gdy sytuacja Olędrów uległa zmianie. Władze pruskie wprowadzały nowe zasady ujednolicenia religii $\mathrm{w}$ ramach unii gmin luterańskich i kalwińskich w kościele krajowym Prus. Zmiany teologiczne i doktrynalne oraz szereg zakazów, a także obowiązkowa służba wojskowa zostały odebrane przez 
część mieszkańców olęderskich osad jako zamach na ich dotychczasowe swobody. Atmosfera stała się na tyle napięta, że wielu mieszkańców Nekielskich Olędrów i okolic zdecydowało się na opuszczenie wiosek i dobrowolną emigrację, głównie do Australii. W 1846 r. około 100 osób z Nekielki i okolic wyruszyło w podróż statkiem „Heloiza” z Bremy do Australii, ich potomkowie żyją $\mathrm{w}$ różnych regionach tego kontynentu i od kilkunastu lat odwiedzają olęderskie wioski okolic Nekli. Decyzje o dalszej migracji spowodowane były także względami ekonomicznymi, bowiem piaszczyste i nieurodzajne gleby nawet pracowitym i doświadczonym Olędrom nie dawały spodziewanych profitów, a życie codzienne upływało najczęściej w niedostatku i biedzie.

Historia pokoleń zaproszonych w okolice Nekli ludzi nazywanych Olędrami wydawała się przez kolejne powojenne lata opowieścią jedynie z minionych czasów. Wojna zerwała wszystkie delikatne więzi, które łączyły niegdyś mieszkańców tych okolic. Pozostały krajobrazy, niszczejące gospodarstwa oraz cmentarze. Nadszedł jednak czas i znaleźli się ludzie, dla których olęderska historia jest ważna, bowiem opowiada o uniwersalnych wartościach życia wypełnionego praca, wiarą i nadzieją. Na tym terenie zawiązano Społeczny Komitet Renowacji Cmentarzy Olęderskich w Gminie Nekla, wytyczono szlak turystyczny oraz nawiązano kontakty z potomkami dawnych Olędrów. Nikogo już nie dziwią zapalane znicze na olęderskich cmentarzach oraz coroczne wizyty "australijskich Olędrów" (Przewoźny, 2016). Na fotografii 10 widoczna jest tablica upamiętniająca dawnych mieszkańców, osadzona w murze przy wejściu do dawnego kościoła luterańskiego - jedynego ocalałego w tych okolicach. Od wielu lat olęderska świątynia jest miejscem spotkań, koncertów oraz wystaw.

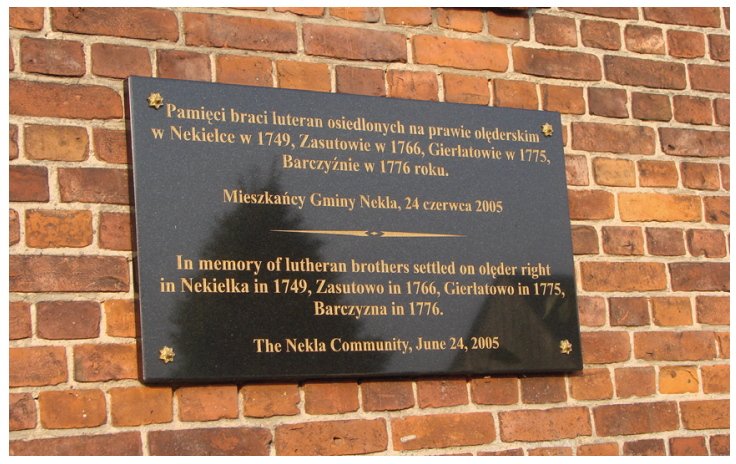

Fotografia 10. Nekielka - tablica upamiętniająca dawnych mieszkańców Zródło: W. Przewoźny (2015) 


\section{Podsumowanie}

Umiejętność „czytania krajobrazu” może okazać się fascynującą przygodą w trakcie przemierzania szlaków turystycznych lub, co czasem ciekawsze, gdy zbacza się z utartych ścieżek, znanych z map i przewodników. Wytyczanie coraz to nowych kierunków podróżowania staje się norma, szczególnie istotną gdy bierze się pod uwagę coraz powszechniejszy typ zaangażowanej turystyki kulturowej. Nie wystarcza naturalny pejzaż, rezerwat unikatowej flory czy fauny, lecz obiektami poznania stają się coraz częściej bardziej ukryte ślady dziedzictwa kulturowego, które wymagają wiedzy i dodatkowego intelektualnego wysiłku. Minimalne poznanie historii przemierzanych terenów, także tych, które przez lata były prawie zupełnie przemilczane, może wyzwolić inne spojrzenie na wydawałoby się mało atrakcyjne układy pól, pozostałości budownictwa drewnianego, zarośnięte kanały, zardzewiałe śluzy i jazy, opuszczone i zapomniane cmentarze. Takie poznawanie zatartych śladów pobytu tysięcy Olędrów może wzbudzać podziw dla ich osiągnięć. Krajobraz, który nadal świadczy o ich obecności, jest na wielu terenach bardzo atrakcyjny i sam w sobie może być dostatecznym powodem, aby te tereny zobaczyć.

\section{Bibliografia}

Burszta, J. (2014). Kolonie „olęderskie” i wsie sołtysie. Osadnictwo pustkowi. W: B. Frydryczak (red.), Krajobrazy. Antologia tekstów (s. 279-284). Poznań: Wydawnictwo PTPN.

Chodyła, Z. (2005). Najstarsze dzieje osad olęderskich w okolicach Nekli w latach 1749-1793. Nekla: Gmina Nekla.

Chodyła, Z. (2007). Zarys dziejów osadnictwa olęderskiego w Polsce (1547-1864). W: W. Przewoźny (red.), Olędry. Przestrzenie obok nas (s. 33-69). Poznań: Muzeum Narodowe w Poznaniu.

Chodyła, Z. (2015). Zarys najstarszych dziejów osad olęderskich w Puszczy Pyzdrskiej 1746-1793. Pyzdry: Lokalna Organizacja Turystyczna Puszcza Pyzdrska.

Frydryczak, B., Angutek, D. (2014). Od krajobrazu naturalnego do krajobrazu kulturowego. Wprowadzenie. W: B. Frydryczak (red.), Krajobrazy. Antologia tekstów (s. 8-16). Poznań: Wydawnictwo PTPN.

Gaworecki, W. (2010). Turystyka. Warszawa: Polskie Wydawnictwo Ekonomiczne.

Klassen, P.J. (2002). Ojczyzna dla przybyszów. Wprowadzenie do historii menonitów w Polsce $i$ Prusach. Warszawa: Wydawnictwo Abora.

Lowenthal, D. (2014). Życie z krajobrazem i oglądanie krajobrazu. W: B. Frydryczak (red.), Krajobrazy. Antologia tekstów (s. 111-138). Poznań: Wydawnictwo PTPN.

Piętka, B. (2000). Spis miejscowości w Polsce. Tom I, II. Katowice: Wydawnictwo PIĘTKA.

Przewoźny, W. (2007). Olędry. Przestrzenie obok nas. W: W. Przewoźny (red.), Olędry. Przestrzenie obok nas (s. 9-20). Poznań: Wydawnictwo Muzeum Narodowe w Poznaniu. 
Przewoźny, W. (2016). Olędrzy - zapomniana historia ludzi i miejsc. W: J. Osypiuk (red.), Nekielskie Olędry. W kręgu pracy, wiary i nadziei (s. 97-115). Nekla: Nekielskie Stowarzyszenie Kulturalne.

Przewoźny, W., Przewoźny, J. (2009). Szlakiem Olędrów w Pótnocnej Wielkopolsce. Zwiedzamy Wielkopolskę. Poznań: Wojewódzka Biblioteka Publiczna Centrum Animacji Kultury.

Słowiński, M. (2006). Drogi wodne w Wielkopolsce. Wielka Pętla Wielkopolski. Poznań: Urząd Marszałkowski Województwa Wielkopolskiego.

\title{
KRAJOBRAZ W TURYSTYCE KULTUROWEJ - PRZYKŁAD OSADNICTWA OLĘDERSKIEGO W WIELKOPOLSCE
}

\begin{abstract}
Abstrakt: Wiejski krajobraz kulturowy coraz częściej stanowi cel turystycznego zainteresowania. Odkrywane są nie tylko zabytki materialnego dziedzictwa, ale także inne, do niedawna nieznane, walory. Do takich należą ślady dawnego osadnictwa na prawie olęderskim. Rozległe łąki, obrośnięte wierzbami i topolami kanały lub samotne gospodarstwa są często jedynymi śladami obecności Olędrów. Razem z wiejską architekturą stanowią atrakcję turystyczną - słyną z tego Żuławy ze swoją mennonicko-holenderską historią. Do olęderskich wiosek zapraszają także w regionie Torunia, Bydgoszczy, Warszawy, Sławatycz. Również w Wielkopolsce podjęło trud promowania poolęderskiego krajobrazu kulturowego (ponad 900 wiosek). Szczególną rolę odgrywają tu okolice Nekli oraz samotne osady Puszczy Pyzdrskiej. Do niedawna wiejskie tereny tych okolic uznawano za mało atrakcyjne (z wyjątkiem rozlewisk Nadwarciańskiego Parku Krajobrazowego). Okazało się, że odkrycie „olęderskiej historii" nadało tym obszarom nowego, niezwykle ciekawego znaczenia.
\end{abstract}

Słowa kluczowe: turystyka kulturowa, krajobraz kulturowy, osadnictwo olęderskie, Olędrzy, Wielkopolska.

\section{LANDSCAPE IN CULTURAL TOURISM: THE EXAMPLE OF AN OLĘDER SETTLEMENT IN WIELKOPOLSKA}

\begin{abstract}
The rural cultural landscape is more and more often a target of tourist interest. Not only are material heritage monuments discovered, but other aspects, until recently unknown, as well. These include traces of a former settlement under Olęder law. Vast meadows, canals overgrown with willows and poplars, or lonely farms are often the only traces of the Olęder presence. Together with the rural architecture with its MennoniteDutch history, they are the tourist attraction which Żuławy is famous for. Olęder villages in the region of Toruń, Bydgoszcz, Warsaw and Sławatycze are also visited. In Wielkopolska efforts have been made to promote the post-Olęder cultural landscape (over 900 villages) and the vicinity of Nekla and the lonely settlements of the Pyzdry Forest play a special role here. Until recently, the rural parts of these areas were considered unattractive (with the exception of the backwaters of the Nadwarciański Landscape Park) but the discovery of "Olęder history" has given these areas a new, and extremely interesting, meaning.
\end{abstract}

Keywords: cultural tourism, cultural landscape, Olęder settlement, Olędrzy, Wielkopolska. 